\title{
PENGARUH PENGETAHUAN DAN SIKAP REMAJA TERHADAP PENERAPAN GIZI SEIMBANG SELAMA MASA NEW NORMAL COVID-19 DI MA DDI ALLIRITENGAE MAROS
}

\author{
Asmiranti. M $^{1}$, St.Masithah ${ }^{2}$, Suherman $^{3}$, Icha dian Nurcahyani ${ }^{4}$, Kurnia Yusuf ${ }^{5}$ \\ Program Studi S1 Gizi, STIKES Salewangang Maros \\ asmiranti.m@gmail.com¹ masyithah.asnawi@gmail.com²
}

\begin{abstract}
Adolescence is an age that is vulnerable to nutrition because of its rapid growth and it takes enough energy to perform a variety of physical activities. In the new normal of Covid-19, it is very important for us to have to improve the immune system which is the body's defense force to fight bacteria, viruses, and disease-causing organisms that we may touch, consume and breathe every day. The purpose of this study is to find out if there is an influence of adolescent knowledge and attitudes on the application of balanced nutrition during the New Normal period of COVID-19 at MA DDI Alliritengae Maros. This type of research is Ex post Facto with quantitative approach, a sample of 65 students selected from a population of 183 students using the formula Sloving. The variables in this study are knowledge and nutritional attitudes balanced with data collection tools using questionnaires or questionnaires with multiple linear regression analysis. The results showed that there is an influence of nutritional knowledge on the application of balanced nutrition judging by the results ( $p<0.05)$, and there is an influence of attitude to the application of balanced nutrition aimed at results $(p<0.05)$. Based on these results, it can be concluded that there is an influence of adolescent knowledge and attitudes towards the application of balanced nutrition during the New Normal period of COVID-19 at MA DDI Alliritengae Maros.
\end{abstract}

Keywords $\quad$ : Balanced Nutrition, Knowledge, Attitude

\begin{abstract}
ABSTRAK
Usia remaja merupakan usia yang rentan gizi karena tumbuh kembang yang begitu sangat pesat dan dibutuhkan energi yang cukup untuk melakukan beragam aktivitas fisik. Pada masa New Normal Covid-19, sangat penting bagi kita untuk harus meningkatkan sistem kekebalan tubuh yang dimana merupakan kekuatan pertahanan tubuh untuk melawan bakteri, virus, dan organisme penyebab penyakit yang mungkin kita sentuh, konsumsi dan hirup setiap hari. Tujuan dari penelitian ini adalah untuk mengetahui Apakah ada pengaruh pengetahuan dan sikap remaja terhadap penerapan gizi seimbang selama masa New Normal covid-19 di MA DDI Alliritengae Maros. Jenis penelitian ini adalah Ex post Facto dengan pendekatan kuantitatif, sampel sebanyak 65 siswa dipilih dari populasi sebanyak 183 siswa dengan menggunakan rumus Sloving. Variabel dalam penelitian ini adalah pengetahuan dan sikap gizi seimbang dengan alat pengumpulan data menggunakan angket atau kuesioner dengan analisis regresi linier berganda. Hasil menunjukkan bahwa ada pengaruh pengetahuan gizi terhadap penerapan gizi seimbang dilihat dari hasil $(\mathrm{p}<0,05)$, dan terdapat pengaruh sikap terhadap penerapan gizi seimbang yang ditujukan dengan hasil $(\mathrm{p}<0,05)$. Berdasarkan hasil tersebut, dapat disimpulkan bahwa ada pengaruh pengetahuan dan sikap remaja terhadap penerapan gizi seimbang selama masa New Normal covid-19 di MA DDI Alliritengae Maros.
\end{abstract}

Kata kunci : Gizi Seimbang, Pengetahuan, Sikap

\section{PENDAHULUAN}

Pengetahuan Gizi Seimbang (PGS) sangatlah penting untuk kita dalam menyiapkan pola hidup sehat dalam "beban ganda masalah gizi”, yaitu kekurangan dan kelebihan gizi yang terjadi bersama-sama. Kekurangan dan kelebihan gizi berdampak buruk terhadap kesehatan dan kualitas hidup manusia. Kekurangan gizi berhubungan erat dengan lambatnya pertumbuhan tubuh (terutama pada anak), 
daya tahan tubuh yang rendah sehingga mudah sakit, kurangnya tingkat inteligensi (kecerdasan), dan produktivitas yang rendah (Waode Fifin Ervin, 2014).

Pengetahuan yang baik diharapkan akan berpengaruh terhadap konsumsi makanan yang lebih baik. Pengetahuan yang dimaksud ialah pengetahuan gizi dan jajanan yang dapat diperoleh melalui pendidikan formal ataupun informal. Adapun sikap yang baik ternyata belum tentu perilaku yang dimiliki juga akan baik, ada banyak faktor yang mempengaruhi perilaku anak yang baik tanpa didasari dengan sikap yang baik. Salah satunya ialah anak meniru kebiasaan orang tua maupun teman sebayanya, yang dapat mempengaruhi perilaku maupun sikap anak dalam memilih makanan.(Aisyah, 2015).

Usia remaja merupakan usia rentan gizi karena tumbuh kembang yang pesat dan dibutuhkan energi yang cukup untuk melakukan beragam aktivitas fisik. Jika pola asupan buruk, akan berdampak pada pertumbuhan dan perkembangan yang tidak optimal, serta lebih rentan terhadap penyakit-penyakit kronis di masa dewasa (Mokoginta, 2016).

Data Riskesdas (2018) menunjukkan bahwa rata-rata prevalensi IMT/U anak umur 13-15 tahun yang tergolong sangat kurus dan kurus di Sulawesi Selatan $(2,46 \%)$ dan $(8,28 \%)$, yang tergolong gemuk di Sulawesi Selatan yaitu $(10,46 \%)$, dan yang tergolong sangat gemuk Sulawesi Selatan yaitu $(4,15 \%)$. Data Riskesdas (2018) di Kabupaten Maros menunjukkan bahwa rata-rata prevalensi IMT/U 13-15 tahun yang tergolong sangat kurus $(5,62 \%)$ dan kurus $(11,16 \%)$, yang tergolong gemuk yaitu $(8,67 \%)$, dan yang tergolong sangat gemuk yaitu $(0,79 \%)$ (Riskesdas, 2018).

Hasil penelitian (Dewi, 2013) pada remaja di program keahlian jaga boga SMK Negeri 6 Yogyakarta menunjukkan bahwa pengetahuan gizi remaja $58 \%$ pada kategori baik, cukup 32\%, dan kurang 10\%, dan sikap terhadap gizi seimbang $48 \%$ pada kategori cukup, kurang $18 \%$ dan baik $34 \%$.

Covid-19 menyebabkan banyak perubahan dalam kehidupan sehari-hari. Mempertahankan pola makan gizi seimbang yang sehat sangat penting dalam meningkatkan sistem kekebalan tubuh yang baik. Pada masa New Normal Covid-19, (Kementerian Kesehatan RI 2020). Meningkatkan sistem kekebalan tubuh yang merupakan kekuatan pertahanan tubuh melawan bakteri, virus, dan organisme penyebab penyakit yang mungkin kita sentuh, konsumsi dan hirup setiap hari. Meningkatkan daya tahan tubuh adalah salah satu kunci agar tidak tertular virus Covid-19, maka dari itu penerapan Gizi seimbang sangat penting untuk sistem kekebalan tubuh (Kementerian Kesehatan RI 2020). Berdasarkan hal tersebut penulis merasa perlu melakukan penelitian "Pengaruh Pengetahuan dan Sikap Remaja Terhadap Penerapan Gizi Seimbang Selama Masa New Normal covid-19 di MA DDI Alliritengae Maros. Adapun tujuan dari penelitian ini adalah untuk mengetahui apakah ada pengaruh pengetahuan dan sikap remaja terhadap penerapan gizi seimbang selama masa New Normal Covid19 di Ma DDI Alliritengae Maros.

\section{METODE}

Jenis penelitian ini adalah Ex post Facto karena variabel bebas dalam penelitian ini tidak dikendalikan atau diperlakukan khusus melainkan hanya mengungkap fakta berdasarkan pengukuran gejala yang telah ada pada diri responden sebelum penelitian ini dilaksanakan.

Penelitian ini dilakukan pada bulan september 2020 di Sekolah MA DDI Alliritengae Maros kecamatan turikale, Kabupaten Maros yang merupakan salah satu sekolah Madrasah Aliyah yang berada di Kabupaten Maros yang beralamatkan di jl.Taqwa No.2 Maros. Sampel sebanyak 65 siswa dari populasi sebanyak 183 siswa menggunakan rumus Sloving. Sampel dipilih dengan kriteria inklusi siswa siswi 
di MA DDI Alliritengae Maros, dan bersedia menjadi responden. Kriteria eksklusi dalam penelitian ini adalah siswa yang tidak memiliki gadget (smartphone).

Persetujuan siswa dalam mengikuti penelitian ini dibuktikan dengan informed consent. Variabel independen dalam penelitian ini adalah pengetahuan dan sikap sedangkan variabel dependen dalam penelitian ini adalah gizi seimbang. Pengumpulan data dengan menggunakan anket atau kuesioner dengan memungculkan beberapa pertanyaan mengenai pengetahuan dan sikap remaja terhadap penerapan gizi seimbang. Data dianalisis dengan menggunakan analisis uji $F$ yang dilakukan untuk mengetahui pengaruh variabel independen (pengetahuan dan sikap) dengan variabel dependen (penerapan gizi seimbang) menggunakan analisis linear berganda.

\section{HASIL}

Berdasarkan karakteristik subjek penelitian diketahui bahwa sebagian besar berjenis kelamin perempuan $(78,5 \%)$. Hasil penelitian dapat dilihat pada tabel-tabel berikut.

Tabel 1. Distribusi Responden Berdasarkan Pengetahuan

\begin{tabular}{ccc}
\hline Pengetahuan & n & \% \\
\hline Baik & 43 & 66,2 \\
Cukup & 17 & 26,2 \\
Kurang & 5 & 7,7 \\
\hline Total & $\mathbf{6 5}$ & $\mathbf{1 0 0 , 0}$
\end{tabular}

Berdasarkan Tabel 1, dapat dilihat bahwa sebagian besar memiliki pengetahuan baik sebesar $(66,2 \%)$.

Tabel 2. Distribusi Responden Berdasarkan Sikap

\begin{tabular}{ccc}
\hline Sikap & N & \% \\
\hline Positif & 63 & 96,9 \\
Negatif & 2 & 3,1 \\
\hline Total & $\mathbf{6 5}$ & $\mathbf{1 0 0 , 0}$ \\
\hline
\end{tabular}

Berdasarkan pada Tabel 2 didapatkan hasil sikap sebagian besar memiliki sikap positif $(96,9 \%)$.

Tabel 3. Distribusi Responden Berdasarkan Penerapan Gizi Seimbang

\begin{tabular}{ccc}
\hline $\begin{array}{c}\text { Penerapan Gizi } \\
\text { Seimbang }\end{array}$ & $\mathbf{n}$ & \% \\
\hline Menerapkan dengan & 32 & 49,2 \\
baik & 22 & 33,8 \\
Menerapkan & 11 & 16,9 \\
\hline Kurang Menerapkan & $\mathbf{6 5}$ & $\mathbf{1 0 0 , 0}$ \\
\hline Total &
\end{tabular}

Berdasarkan pada Tabel 3, dapat terlihat hasil bahwa sebagian besar menerapkan gizi seimbang dengan baik $(49,2 \%)$.

Tabel 4. Uji Pengaruh Pengetahuan dan Sikap Terhadap Penerapan Gizi Seimbang

\begin{tabular}{lrcc}
\hline & Variabel & n & p-value \\
\hline $\begin{array}{l}\text { Penerapan } \\
\text { Gizi }\end{array}$ & Pengetahuan & 65 & 0,006 \\
Seimbang & & & \\
& Sikap & 65 & \\
\hline
\end{tabular}

Berdasarkan hasil uji $\mathrm{F}$ pada analisis regresi linear berganda pada Tabel 4, diketahui bahwa ada pengaruh yang signifikan pengetahuan dan sikap terhadap penerapan gizi seimbang $(\mathrm{P}<0,05)$.

\section{PEMBAHASAN}

Hasil penelitian menunjukkan bahwa terdapat pengaruh pengetahuan gizi terhadap penerapan gizi seimbang pada siswa/i MA DDI Alliritengae Maros dengan nilai sig $0,006<0,05$. Hal ini terjadi karena semakin baik tingkat pengetahuan gizi responden maka akan baik pula dalam menerapkan gizi seimbang.

Hal ini sesuai dengan hasil penelitian yang dilakukan oleh Rima Nurdzulqaidah (2017) yang menunjukkan bahwa ada hubungan pengetahuan gizi seimbang dengan sikap dan perilaku gizi seimbang. Karena disebabkan tingkat pengetahuan seseorang mengenai pentingnya kandungan gizi dan manfaatnya bagi kesehatan akan 
merubah perilaku maupun sikap gizi seimbang suatu individu itu sendiri. Sama halnya dengan hasil penelitian yang dilakukan pada mahasiswa Institut Pertanian Bogor (IPB) yang menunjukkan adanya hubungan yang bermakna antara pengetahuan gizi seimbang dengan sikap gizi seimbang. Seorang individu yang memiliki pengetahuan yang baik akan memiliki sikap dan perilaku gizi seimbang yang baik pula.

Pengetahuan merupakan hasil tahu dari seseorang terhadap objek melalui indera yang dimilikinya (mata, hidung, telinga dan sebagainya). Sebagian besar pengetahuan diperoleh melalui indera pendengaran (telinga) dan indera penglihatan (mata) Notoadmojo (2010). Pengetahuan gizi yang baik diharapkan mempengaruhi konsumsi makan yang baik sehingga dapat menuju status gizi yang baik pula. Pengetahuan gizi juga mempunyai peranan yang sangat penting dalam pembentukan kebiasaan makan seseorang.

Pendidikan dan pengetahuan gizi dapat sangat membantu seseorang dalam menerapkan hidup sehat dengan cara memperoleh informasi dalam pemilihan makanan yang tentunya berguna bagi tubuh seseorang (Supariasa, 2012). Berdasarkan hasil penelitian yang dilakukan oleh Maria (2019) mengatakan bahwa memang terdapat pengaruh maupun hubungan antara kebiasaan makan dengan status gizi seorang remaja.

Sikap merupakan suatu yang masih bersifat abstrak, dapat didasarkan pada keyakinan yang ada pada setiap individu (yang berkaitan dengan kognitif) dan sering kali sikap dipengaruhi oleh perasaan (yang merupakan komponen emosional) sehingga dapat membawa atau menentukan perilaku tertentu (Notoadmojo 2005). Selanjutnya Sodiaoetama (2000) berpendapat bahwa kesalahan dalam memilih makanan yang kurang cukupnya pengetahuan tentang gizi akan mengakibatkan timbulnya sebuah masalah gizi. Status gizi yang baik tercapai dengan pola makan yang baik, yaitu yang didasarkan atas prinsip menu seimbang, alami, dan sehat.

Hasil penelitian menunjukkan bahwa terdapat pengaruh yang signifikan antara sikap gizi terhadap penerapan gizi seimbang pada siswa/i MA DDI Alliritengae Maros dengan nilai sig $0,006<0,05$. Terjadi karena sikap merupakan tahapan yang lebih lanjut dari pengetahuan gizi dalam penelitian ini sebagian besar didapatkan bahwa pengetahuan yang baik dan dengan sikap yang positif maka akan baik pula penerapan gizi seimbang. Hal ini sesuai dengan hasil penelitian yang dilakukan oleh Suci S Puji (2011) yang menyatakan bahwa ada pengaruh atau hubungan yang bermakna antara sikap gizi dengan penerapan pola makan gizi seimbang degan nilai $P$-Value $<$ 0,05 .

Hal ini sesuai dengan teori yang dikemukakan oleh peneliti terdahulu bahwasanya ada pengaruh hubungan yang sangat erat antara pengetahuan dan perilaku gizi seimbang. Karna pada umumnya pengetahuan dan sikap akan mempengaruhi perilaku mengenai gizi seimbang (Renata Patricia \& Anna Maria Dewajanti 2017). Sikap merupakan respon evaluative, respon yang timbul apabila seseorang individu dihadapkan dengan stimulus yang akan menghendaki adanya reaksi suatu individu. Sikap yang didasari oleh proses evaluasi dalam diri individu yang memberikan kesimpulan terhadap stimulus dalam bentuk nilai baik buruk, positif negative, menyenangkan tidak menyenangkan sesuai potensi reaksi terhadap objek sikap (Azwar,2007).

Dalam Teori Khomsan (2000) yang mengungkapkan bahwa sikap terhadap gizi merupakan tahapan yang lebih lanjut dari pengetahuan gizi. Seseorang yang berpengetahuan gizi baik akan mengembangkan gizi yang baik. Sikap akan mengarahkan perilaku secara lansung. Dengan demikian sikap positif akan menumbuhkan perilaku yang positif dan sebaliknya sikap negatif akan menumbuhkan perilaku yang negatif, 
dalam hal ini lebih mengarah pada perilaku memilih makanan dan menerapkan gizi seimbang dalam kehidupan sehari-hari.

\section{KESIMPULAN}

Hasil penelitian yang telah dilakukan oleh peneliti tentang pengaruh pengetahuan dan sikap remaja terhadap penerapan gizi seimbang dapat disimpulkan sebagai berikut pengetahuan gizi remaja terhadap penerapan gizi seimbang selama masa new normal Covid-19 43 siswa $(66,2 \%)$ pada kategori baik, cukup 17 siswa $(26,2 \%)$ dan kurang $5(7,7 \%)$ sikap gizi remaja terhadap penerapan gizi seimbang selama masa new normal Covid-19 63 siswa $(96,9 \%)$ pada kategori positif dan 2 siswa $(3,1 \%)$ pada kategori Negatif.

Ada Pengaruh pengetahuan terhadap penerapan gizi seimbang dengan nilai sig $0,006<0,05$. Ada Pengaruh sikap terhadap penerapan gizi seimbang dilihat dari hasil nilai sig $0,006<0,05$.

\section{UCAPAN TERIMAKSIH}

Peneliti mengucapkan terimakasih kepada Pihak Sekolah MA DDI Alliritengae Maros yang telah mengizinkan peneliti melakukan penelitian ini beserta semua responden. Dosen pembimbing serta semua rekan sejawat yang selalu memberikan dukungan.

\section{DAFTAR PUSTAKA}

Aisyah (2015) Hubungan Pengetahuan dan Sikap Anak terhadap Perilaku Pemilihan Makanan Jajanan yang Sehat di SD Muhammadiyah 16 Karangasem Surakarta. Skripsi.Surakarta:Universitas Muhammadiyah Surakarta.

Azwar,S.(2007) Sikap Manusia Teori dan Pengukurannya. Yogyakarta: Pustaka Belajar.

DewiSR. (2013). Hubungan Antara Pengetahuan Gizi, Sikap Terhadap Gizi Dan Pola Konsumsi Siswa
Kelas XII Program Keahlian Jasa Boga Di SMK Negeri 6 Yogyakarta.Skripsi Program studi Pendidikan Teknik Boga. Fakultas Teknik. Universitas Negeri Yogyakarta.

Kementerian Kesehatan RI. (2020). Panduan Gizi Seimbang pada Masa Pandemi COVID-19. :32.

Khomsan (2000) Teknik Pengukuran Pengetahuan Gizi Jurusan Gizi Masyarakat dan Sumberdaya Keluarga,Fakultas Pertanian Bogor.

Maria Goreti Pantaleon (2019) Hubungan Pengetahuan Gizi Dan Kebiasaan Makan Dengan Status Gizi Remaja Putri Di SMA Negeri II Kota Kupang. CHMK HEALTH JOURNAL, Vol.3 No.3,September 2019.

Mokoginta (2016). Gambaran Pola Asupan Makanan Pada Remaja di Kabupaten Bolaang Mongondow Utara. Jurnal e-Biomedik Vol.4.No 2. Diakses 22 agustus 2020.

Nana Sudjana dan Ibrahim (2001) penelitian dan Penilaian Pendidikan. Bandung :Sinar Baru Algensindo.

Notoatmodjo (2010) Promosi Kesehatan Teori dan Aplikasi. Jakarta: Rineka Cipta.

Notoatmodjo S (2005) Promosi Kesehatan Teori dan Aplikasi. Jakarta: Rineka Cipta.

Patricia Renata \& Anna Maria Dewajanti (2017) Hubungan Pengetahuan, Sikap, dan Perilaku Tentang Gizi Seimbang Dengan Status Gizi Siswa Kelas IV dan V di Sekolah Dasar Tarakanita Gading Serpong. Journal Kedokteran Meditek Vol.23.No.61 Jan-Maret 2017.

Rima Nurzulqaidah (2017) Hubungan Pengetahuan Gizi Seimbang Dengan Perilaku Gizi Seimbang Mahasiswa Tingkat 4 Angkatan 2013 Fakultas Kedokteran Universitas Islam Bandung. Skripsi.Fakultas Kedokteran 
Universitas Islam Bandung.

Riskesdas.(2018). Laporan Provinsi

Sulawesi Selatan RISKESDAS 2018.

Sodiaoetama, Achmad Djaeni (2000). Ilmu

Gizi Untuk Mahasiswa dan Profesi

Jilid 1. Jakarta : Dian Rakyat.

Suci S puji (2011). Faktor-faktor Yang

Berhubungan Dengan Pola Makan

Mahasiswa Kesehatan Masyarakat

Fakultas Kedokteran Dan Ilmu

Kesehatan Universitas Islam Negri

Syarif Hidayatullah Jakarta Tahun

2011.Skripsi program Studi

Kesehatan Masyarakat UIN Syarif

Hidayatullah Jakarta.

Supariasa (2012) Pendidikan dan Konsultasi Gizi. Jakarta: EGC.

Waode Fifin Ervin. (2014.)Hubungan Pengetahuan Dan Sikap Dengan Perilaku Gizi Seimbang Pada Wanita Prakonsepsi Di kota Makassar. 